\title{
Experiences on the Implementation of Child Protection Policies
}

\author{
Hazel S. Zamora \\ Graduate Student, Master of Arts in Educational Management, Davao del Norte State College, Philippines
}

\begin{abstract}
This study aims to determine the experiences of school heads in the Division of Panabo City on implementing the Child Protection Policy (CPP). An in-Depth Interview (IDI) and Focus Group Discussion (FGD) were conducted to confirm and validate the responses of the school heads. Findings revealed that school heads faced challenges such as the lack of adequate financial and human resources and the negative dispositions of students. In addressing such challenges, it was noted that school heads strictly implemented the policy's provisions, sought the assistance of various stakeholders, and implemented strong communication efforts. It was then learned that an effective CPP implementation might only happen if school heads employ childcentered and policy-based decision making, establish positive relationships with stakeholders, and strengthen the school's communication mechanisms. Overall, it is recommended that school heads enjoin stakeholders to participate in the decisionmaking and implementation of the policy, build relationships with parents, and launch school initiatives following the law, CPP program, and DepEd vision, mission, and core values.
\end{abstract}

Keywords- Philippines, phenomenological approach, Child Protection Policy, elementary

\section{INTRODUCTION}

$\mathrm{C}$ hildren are recognized as competent social actors with valuable perspectives and knowledge that hold fundamental rights who actively interact with their social world (Corsaro, 2011; Central to this understanding is the idea that everyone must ensure that children are protected from abuse, neglect, and violence.(United Nations Children's Fund [UNICEF], 2016a).

In its latest findings, the WHO's Global Status Report on Preventing Violence Against Children (2020) stated that one out of two children or 1 billion children suffer from some form of violence each year, and children aged 11-15 who are bullied at school are 13\% less likely to graduate from school. In this sense, the leadership of school heads is essential to the success of child protection school-based programs Committee for Children, (2014). Furthermore, school leaders must review their present child protection policies and procedures in order to create a complete child protection strategy for their school that is consistent with current research and best practices. (Committee for Children, 2014).

In the Philippines, different forms of abuse are experienced by one in two Filipino school children, and 50\% of Filipino students are being bullied in school (Ancho \& Park, 2013). In the 2019 comprehensive study of VAC in Philippine schools conducted by UNICEF, Plan International, and the Council for Welfare of Children in 2009, it was found out that there were at least 4 out of 10 children aged 6 to 10 (Grades 1-3) and 7 out of 10 aged 9 to 13 years old (Grades 4-6) and high school students aged 12 to 17 who had experienced violence in school (UNICEF, 2016b). The study also found out that children experience violence from their classmates and school personnel. Simultaneously, sexual harassment is the most common type of sexual assault in elementary and secondary schools, with females being more vulnerable (UNICEF, 2016).

As it can be remembered, in 2012, DepEd issued a child protection policy geared towards providing special protection to children, especially those who are seriously threatened by their vulnerabilities to some circumstances that may hinder their development and learning in school. 2012, entitled "DepEd Child Protection Policy (CPP)" or also known as the "Policy and Guidelines on Protecting Children in School from Abuse, Violence, Exploitation, Discrimination, Bullying, and other forms of Abuse." The article stated that school staff members play a central role in this coalition-from working directly with children who have been exposed to violence to reaching out to parents and intersecting with law enforcement personnel. Additionally, to strengthen the protection of children, the RA 10627 entitled 'An Act Requiring All Elementary and Secondary Schools to Adopt Policies to Prevent and Address the Acts of Bullying in Their Institutions' or otherwise known as the Anti-Bullying Act of 2013, was promulgated. But despite all the tenets set by the government, there are some indications that teachers and school authorities have found it difficult to uphold and keep hold of solid and sustainable school-based protection policies for school children.

As administrators, their role is to implement the child protection policy with a code of conduct and a plan to secure child protection and safety. The researcher was then prompted to conduct a study to determine the experiences of elementary school heads in Panabo City on implementing the child protection policy.

The purpose of this phenomenological study is to determine the experiences of elementary school heads of Panabo City Division and how they overcome the challenges on the implementation of Child Protection Policies as well as their success stories given the delicate and enormous task of protecting learners from any form of abuse in school and the community. 


\section{Theoretical Lens}

This study was anchored in the 1987 Philippine Constitution and the United Nations Convention on the Child's Rights (UNCRC) (1989). These legal and international principles are the bases of policy framework, management decisions, and educational implications where this study stems from. These principles were selected to give legal and theoretical insights into the gaps between the experiences on implementing child protection policies of elementary school's heads in Panabo City Division. Moreover, as the study aims to present the lived experiences of elementary teachers, school heads, and parents regarding child protection policies and practices, it is pertinent that the fundamental frameworks are understood.

In this respect, the constitution also recognized the role of education institutions in protecting the rights of the children as it stated that "All educational institutions shall inculcate patriotism and nationalism, foster love of humanity and respect for human rights, appreciation of the role of national heroes in the historical development of the country, teach the rights and duties of citizenship, strengthen ethical and spiritual values, develop moral character and personal discipline, encourage critical and creative thinking, broaden scientific and technological knowledge, and promote vocational efficiency." (Article XIV, Section 3 [2]).

To gain insight into the phenomenon of the experiences of school heads in the implementation of CPP, this study was examined through the critical lens of Robert Katz's (1955) Three-Skills Approach and Mumford, Zacarro, and Harding's (2000) Skills Approach Model, which later advanced and complimented the earlier work of Katz. The central idea of the skills approach is that a good leader possesses a core set of skills that can be developed to increase a leader's capability (Katz, 1955 in Jeffrey, 2016). According to Katz in 1955 (Jeffrey, 2016), three skills are requisite for a leader to be effective: technical skills, human skills, and conceptual skills.

The child welfare literature emphasizes the lack of preparedness and training of child welfare managers, and it discusses their development. Additionally, Katz's (1955), as cited by Jeffrey's (2016) model, emphasizes ability and not innate skills. The skills model takes a leader-centered approach. It implies that a leader lacking in requisite skills can attain skill and capability with the proper training intervention because leadership skills can be taught (Northouse, 2012).

\section{METHODOLOGY}

\section{Research Design}

A qualitative method was used to describe the experiences of school heads in Panabo City Division on implementing child protection policies in elementary schools. According to Creswell (2014), a phenomenology is a qualitative approach in which the researcher describes the lived experiences of persons concerning a phenomenon as described by participants.

\section{Research Locale and Sampling}

This study was conducted in the DepEd Division of Panabo City. This division is divided into four (4) elementary school districts, namely: Panabo North District (PND), Panabo Central District (PCD), Panabo South District 1 (PSD1), and Panabo South District 2 (PSD 2). The district is headed by a Public Schools District Supervisor (PSDS), while each school is headed by a principal and school head. The schools were Katualan Elementary School (PSD1), New Visayas Central School (PSD2), Licanan Elementary School (PSD2), Salvacion Elementary School (PCD), Gredu Elementary School (PCD), Roxas Elementary School (PND), and Concordia A. Sison Elementary School (PND). Together with all the private and public schools in the country, these schools are mandated to implement DepEd Order no. 40 s. 2012 or the DepEd Child Protection Policy.

This study considered a group of qualified participants who were purposely selected to be part of this study. In selecting the key participants, purposive sampling was used for seven (7) school heads of elementary schools under Panabo South Districts 1 and 2, Panabo Central District, and Panabo North District. The key informants in the In-Depth Interview (IDI) were selected according to the profiling of CPPI who implemented child protection policies and practices for more than five (5) years. Likewise, two (2) principals, two (2) CPP Coordinators, and two (2) parents were chosen as participants in the Focused Group Discussion (FGD). The FGD was conducted to enrich the information gathered from KII and give additional information that the KII informants were not seen and revealed.

\section{Research Instrument}

A researcher-made interview guide was developed. It was validated by two master teachers and one education program supervisor. An interview guide with one (1) grand tour question composed of three (3) sub-questions was prepared. The questions elicited responses regarding the challenges faced by the school heads, coping strategies, and insights that informants shared on the implementation of school-based CPP.

Before the research instrument was used in the field, it was piloted to three school heads who were not included in the IDI. The purpose of the pilot interview was to ensure that the questions would generate plausible answers upon the interview. Then, an Interview Analysis Sheet was prepared to create a set of analytic notes to accompany each interview.

\section{Data Gathering Procedures}

Ask permission to conduct the study in the Division of Panabo City; upon the approval of the SDS, the researcher sent a letter request to the identified seven school heads to allow the gathering of the relevant data. Likewise, two (2) principals, two (2) CPP Coordinators, and two (2) parents were chosen as participants in the Focused Group Discussion (FGD). The FGD was conducted to enrich the information gathered from 
KII and give additional information that the KII informants were not seen and revealed.

\section{Data Analysis Procedure}

After collecting desired data from the IDI and through the FGD, a qualitative analysis of the data was done.

To develop themes tackling the leadership and managerial experiences of elementary school heads in the Division of Panabo City on CPP implementation. In this study, the collection of open-ended data was based on the general questions asked by the informants and participants and developing analysis from the information provided by the participants. Three steps were undertaken in data analysis patterned after Creswell's qualitative data analysis (Creswell, 2009).

First, data reduction was made so that significant statements obtained from the transcribed data were cut down and organized. Then, data was displayed in a table. During the coding process, responses were grouped to generate detailed descriptions of the participants' experiences on the implementation of CPP in their schools. It was then utilized to create themes to be analyzed. Third, themes were formulated to categorize the data and were presented by research questions. Data were organized into brackets and chunks representing categories in margins. Such themes were also referred to as central themes. From the significant themes, core ideas generated from the responses of the participants were also manifested. Lastly, drawing conclusions and verification of the data were done by pointing out the main ideas and recurring patterns in the findings.

\section{Ethical Considerations}

The study was conducted using verbal and written consent forms. Written communication was prepared to request approval for the conduct of the study. And to seek endorsement from the Schools Division Superintendent (SDS). Additionally, each informant received and signed a letter outlining the research and a consent form for participation. All informants were assured of their confidentiality. The researcher retained all transcripts, notes, and an audio recorder.

\section{RESULT AND DISCUSSION}

\section{Demands of Policy Implementation}

It was found out that school heads were struggling to realize such demand in the policy for a couple of problems, such as the lack of monetary and human resources, infrastructure problems, teacher dynamics, and contextualization policy.

Viennet and Pont (2017) also pointed out that the inadequacy of organizational resources and the actors' capacity or reactions against reforms remained a challenge to implementing education policy.

Moreover, school heads are expected to lead in any policies imposed in the bureaucracy of the Philippine Department of
Education. Any policy implementation is indeed demanding and requires leadership and commitment to those who are involved. A strong partnership among the school and community leaders is needed to realize the vision of the policy.

\section{Pupil's Behavior and their Difficult Circumstances}

Children's early experiences shape who they become and will undoubtedly have an influence on their long-term health and upbringing. Unleashing a child's full potential necessitates a safe and stable environment, enough and nutritious food, access to medical care, secure relationships with adults, loving and responsive parenting, and high-quality learning opportunities at home and at school (Sandstrom \& Huerta, 2013).

In their synthesis, Sandstrom and Huerta (2013) posited that studies show many children facing instability in their lives. This instability is manifested in their attitudes and behaviors, especially when they are in school, which have contributed to the implementation of CPP in elementary schools.

The behaviors of pupils are among the prime pressing issues that most school heads and teachers are facing. Their actions in school are manifestations of the kind of environment they are exposed to and the traits of adults surrounding them. It is essential that schools bridge the gap by developing programs to help at-risk children and those having difficulties managing their school and personal lives.

\section{Teachers' Attitude and their Understanding of the Policy}

Teachers' attitudes, such as being indifferent and irresponsible towards their students, were found to be one of the reasons why CPP implementation remained a struggle for many of the school heads. In this case, the teacher's negative attitude towards classroom management prevented them from fostering an environment where the children's welfare was supposed to be uplifted.

Ulug et al. (2013) recommended that since teachers are the second-highest determining factor in the development of individuals, next to parents, teachers should have a positive attitude towards them and should create an environment where children's welfare is protected.

Therefore, school heads should be knowledgeable about the policy contents before communicating it to the teachers and stakeholders. When school heads are credible in policy communication and implementation, strong support from the school and community implementers follows.

Coping strategies on the Challenges Faced by Elementary School Heads on the Implementation of CPP Monitoring, Coordinating, and Communicating School Operations to Various Stakeholders

When faced with overwhelming challenges in the implementation of CPP, school heads reported that they sought the assistance of the local government units such as barangay officials as well as the help of parents. As CPP was 
designed to be collaborative, school heads leveraged their networks and relationship with the community to streamline the policy implementation.

In this way, the duties and responsibilities of school heads and teachers in the policy were lessened. This was also their way to ensure efficient and effective policy implementation and monitoring. Parallel to this situation, Fernandez and Rainey (2006) emphasized the necessity of overcoming stakeholder opposition in order to develop support, offer a change plan and resources, and find a means to integrate the policy in everyday routines in order to make the change sustainable.

\section{Recognizing the Role of Stakeholders in the Policy Implementation}

Despite the challenges encountered with parents, their sole involvement in implementing the CPP was also a huge help, and the school head needs to recognize them. Aside from that, since parents are knowledgeable about their children's rights and the programs that protect them from any form of abuse and violence, bullying and other forms of maltreatment to students are avoided. Cardona et al. (2015) enunciated that parenting styles directly affect the attitude and behavior of the students in Binakayan National High School, Kawit, Cavite, Philippines. With parental guidance, children's rights and welfare were kept under surveillance.

When the relationship is strong, and school leaders recognize partnerships, this will eventually lead to greater involvement of parents. In effect, it lowers the risk of issues related to child protection in schools and the community.

\section{Knowledge Sharing Practice}

Sharing of best practices was beneficial among school heads, division superintendents, and experts to know each other's strategies in dealing with problems in CPP implementation.

This kind of sharing practice was reported by Patzer (2020) as an excellent strategy to encourage teacher collaboration and impactful professional development. Indeed, this helped teachers improve their subject knowledge, teaching strategies and earn new ideas for their classes. It was reported that when teachers use collaborative practices, they become more innovative and had higher job satisfaction (Patzer, 2020). School heads should always seek guidance from experts to facilitate and communicate the policies intended to children and stakeholders.

\section{Leading a Child-centered and Policy-based Institution}

Child-centered and policy-based education is a set of attitudes, skills, and considerations that affect the approaches for the learners. It accepts that each student is unique and values the importance of learners and teachers' relationships (Dix, 2012). This has been one of the means of overcoming challenges on the implementation of CPP in elementary schools.

To support the coping strategies of elementary school heads, well-crafted policy guidelines and protocols must be established in the Department of Education to provide solid procedures in handling child-related cases which involve other stakeholders and government agencies. If these are properly enforced, school heads will be guided in enforcing the policy in their respective schools without fear of breaking the rule of law.

Insights Learned by Elementary School Heads on the Implementation of CPP Child-centered and Policy-based Decision Making

A significant insight noted from the school heads in their experiences of CPP implementation was the importance of policy-based decision-making. For school heads, policy-based decision-making was about putting the interest and welfare of the students at the center of their decision-making process. By anchoring every school decision on the policy, school heads can assure that they are pursuing the right track, and in the event where conflicts arise, they are confident to face them because they are not guilty of any lapses on their part.

Dempster et al. (2004) made a clear statement as to why school principals need to be knowledgeable on the policy to carry out their roles in it effectively. Leadership requires constant decision-making, and it is a practice that school heads must master. School heads should make sound decisions to influence instructional and management practices. Their decisions should be based on the policy to avoid confusion and foster strong support among school partners.

\section{Personal and Professional Realizations}

School heads are human beings who are imperfect even if guided with leadership principles and values. Along the way, effective school heads evaluate their actions and decisions based on their successes and challenges. A critical reflection that school heads realized in overcoming the challenges of implementing CPP in their school was the taking of accountability during difficult situations.

Ethically, Hunt (2002) views accountability as the readiness or preparedness to explain or justify to relevant stakeholders for one's judgments, intentions, acts, and omissions when appropriately called upon to do so.

Therefore, it must be the practice of school heads to make daily personal and professional reflections to assess the decisions being made, the relationship established among school partners, the instructional practices in school, and many more. Without this, school heads will not be able to commit to the demanding job and bring out contextualized policies that fit the school's contexts.

\section{Leadership Reflections}

Aside from personal and professional realizations, there are also leadership reflections that school heads realized during the implementation of CPP. First was that leadership in CPP implementation created an impact in the lives of the children. 
Louis et al. (2010) offered a definition of "leadership" that is distilled from the essence of their findings: leadership is all about organizational improvement; more specifically, it is about establishing agreed-upon and helpful directions for the organization in question and doing whatever it takes to prod and support people to move in those directions.

In addition, leadership is a mandatory requirement for school heads in implementing child protection policy since protecting children from any harm and abuse is a priority and why an educational institution exists.

\section{Communication as a Bridge for Policy Understanding}

School heads understood that for their stakeholders and the community to execute their roles in the implementation of $\mathrm{CPP}$, there has to be a robust understanding of the policy. But to attain this level, school heads should have a communication plan, laying out their strategies on how to effectively raise awareness that would eventually influence their stakeholder's mindset, attitudes, and behaviors towards the policy.

There is rich and untapped information from the school heads' experiences on the CPP implementation that executive leaders must listen to. These data can be found on the decisionmaking practice of school leaders, personal and professional experiences, leadership reflections, and communication strategies that they employ to implement CPP properly in their school with meager financial and human resources.

\section{Implications for Practice}

For schools to have a robust implementation of CPP, school heads, as the chairpersons of the child protection committee, should strictly monitor, evaluate, and initiate efforts to sustain the salient activities of the school relating to CPP implementation such as home visitations, increasing selfefficacy of teachers to implement the policy, following legal procedures in addressing conflicts, parents orientations about the policy, and one-on-one student-teacher consultations.

Moreover, security personnel must be given orientation and training on CPP provisions to be aware of their roles and responsibilities in CPP implementation, and structures like school fences must be put in place to keep.

\section{Implications for Future Research}

The phenomenological inquiry employed in this qualitative study initiates evidence-based information utilized by the Philippines's central and regional Department of Education offices and the public and private elementary schools to enhance the implementation of the CPP in the country.

The research is qualitative, and the experiences of the informants and participants cannot be generalized to the whole school population of Panabo City; thus, it is recommended that future researchers may add more participants and schools to gather more information through interviews and FGDs regarding their successes and challenges in the CPP implementation.

\section{CONCLUSION}

This study uncovered the situation of CPP implementation of the elementary school in Panabo City wherein the challenges encountered by CPP implementers, school heads, teachers, and parents were presented, as well as the strategies they employed to address the challenges the insights gained from their experiences. The findings showed that elementary school heads in Panabo City exuded the needed leadership, people skills, and management practices to strengthen and facilitate the CPP program's effective implementation.

It is with optimism that the generated findings in this undertaking would serve as an aid to push forward and strengthen the protection mechanisms for the DepEd learners. With the results presented, school authorities should identify localized and contextualized activities and programs to bring all stakeholders to share a shared vision of making children go to school and foster in them a sense of security while learning.

Finally, the researcher hopes that this study may propel discussions in congress to be able to establish a uniform government framework and law on the CPP implementation and that a standardized support mechanism for teachers and school personnel will be realized as proposed by House Bill No.5735 or the Student Discipline and Teacher Protection Act which can help teachers and implementers to be protected while performing their responsibilities in this program since child protection is a sensitive and delicate issue.

\section{REFERENCES}

\section{Books:}

[1] Albert, J., David, C., \& Vizmanos, J. (2018). Barriers and bottlenecks to school attendance: an update. Philippine Institute for Development Studies. no. 2018-17. issn 2508-0865

[2] Creswell, J. W. (2014). Research Design: Qualitative, Quantitative and Mixed Methods Approaches (4th ed.). Thousand Oaks, CA: Sage.

[3] Creswell. J.W. (2008). Research design, qualitative, quantitative and mixed method approaches, 3rd Edition, Page Publications Inc.

[4] Educational Facilities Manual (2010) (Revised Edition of the Handbook, on Educational Facilities - Integrating Disaster Risk Reduction in School Construction

[5] Perry, B. D. \& Szalavitz, M. (2010). Born for love. William Morrow Books.

Journals:

[1] Ancho, I. V., \& Park, S. (2013). School violence in the philippines: a study on programs and policies. Advanced Science and Technology Letters, 36, 27-31.

[2] Asio, J. M. R., A Bayucca, S., \& Jimenez, E. (2020). Child protection policy awareness of teachers and responsiveness of the school: their relationship and implications. Shanlax International Journal of Education, 9(1), 1-10.

[3] Bayucca, S. (2020). Teachers' awareness and school's responsiveness to the child protection policy: basis for a development plan. International Journal of Multidisciplinary Research Review 4(6):59-65.

[4] Cardona, R., Reyes, A., \& Tangalin, M. (2015). The bullying experiences and classroom discipline techniques in an urban national high school in the philippines: a basis for an antibullying program. American International Journal of Contemporary Research. 5(2), 49-52.

[5] Castro, M., Expósito-Casas, E., López-Martín, E., Lizasoain, L., 
Navarro-Asencio, E., \& Gaviria, J. L. (2015). Parental involvement on student academic achievement: A Meta-Analysis. Educational Research Review, 14, 33-46.

[6] Cervancia, J. M., Hernandez, K. U., Rodavia, M. R., \& Roxas, E. (2019). Child abuse and compliance on child protection policy in private and public basic educational institutions. International Journal for Cross-Disciplinary Subjects in Education (Ijcdse), 10(1), 3957-3958. Retrieved from: https://bit.ly/35faxrb

[7] Cardona, R., Reyes, A., \& Tangalin, M. (2015). The bullying experiences and classroom discipline techniques in an urban national high school in the philippines: a basis for an antibullying program. American International Journal of Contemporary Research. 5(2), 49-52.

[8] Department of Education and Training. (2004). Regulatory framework cd. fornell, c., \& larcker, d. (1981). evaluating structural equation models with unobservable variables and measurement error. Journal of Marketing Research, 18, 39-50.

[9] Ilhan, F., Ozfidian, B., \& Yilmaz, S. (2019). Home visit effectiveness on students' classroom behavior and academic achievement. Journal of Social Studies Education Research, 10(1), 61-80. Retrieved from: https://bit.ly/3zre8ir

[10] Mumford, M. D., Zaccaro, S. J., Harding, F. D., Jacobs, T. O., \& Fleishman, E. A. (2000). Leadership skills for a changing world: Solving Complex Social Problems. The Leadership Quarterly, 11(1), 11-35.

[11] Jeffrey, J. R. (2016). Essential in the middle: training, preparation, and development of child protection middle managers. Education Doctoral. Paper 263.

[12] Patzer, R. (2020, February). Sharing good practice: Strategies to Encourage Teacher Collaboration. Irisconnect.Com. Retrieved from: https://bit.ly/3cdk9bq

[13] Save the Children. (2011). Child protection in the philippines: A Situational Analysis. Save The Children, Bangkok.

[14] Sandstrom, H., \& Huerta, S. (2013). The negative effects of instability on child development: A Research Synthesis. Washington, Dc: Urban Institute

[15] Viennet, R., \& Pont, B. (2017). Education policy implementation: A Literature Review and Proposed Framework. Oecd Education Working Papers, No. 162. Oecd Publishing.

[16] Ulug, M., Ozden, M. S., \& Eryilmaz, A. (2011). The effects of teachers' attitudes on students' personality and performance. Procedia-Social and Behavioral Sciences, 30, 738-742.

\section{Websites:}

[1] Article 218 of the Family Code of the Philippines (1987). Retrieved from: https://bit.ly/3gw8QTt

[2] Article XV, Section 3 (2), 1987 Constitution. Retrieved from: https://bit.ly/35f3c31

[3] Bernardo, J. (2021, January 4). Deped calls on schools to strengthen child protection efforts. Retrieved: May 23,2017 AbsCbn News. from: https://bit.ly/35gjt7b

[4] Berson Y.\& Orig S. (2016) The role of school principals in shaping children's values Retrieved from: https://bit.ly/3zuAngG

[5] Caguiat, G. (2020, September 16). Parenting education abates violence, bullying in schools. The Manila Times. Retrieved from: https://bit.ly/2U4wsbv

[6] Committee for Children. (2014). Child protection in schools: A Four-Part Solution, Design Qualitative, Quantitative, And Mixed Methods Approach. Third Edition. University of Nebraska-Lincoln
Retrieved from: https://bit.ly/3zmbejb

[7] Corsaro, William. (2011) Article in European Early Childhood Education Research Journal · DOI: 10.1080/13502930085208591 Retrieved from: https://bit.ly/3gFCZQd

[8] Council for Welfare of Children 2009. Convention on the rights of the child. united nations: geneva. $\mathrm{CRC} / \mathrm{C} / \mathrm{PHL} / \mathrm{CO} / 3-4 R$ etrieved from: https://bit.ly/3cT0oMZ

[9] Department of Education (DepEd) (2012). May 14, 2012 do 40, s. 2012 - deped child protection policy.www.deped.gov.ph. Retrieved from: https://bit.ly/3wfs8or

[10] Department of Education (DepEd) order no. 55, s. 2013 Implementing rules and regulations (irr) of republic act (ra) no. 10627 Otherwise Known as The Anti-Bullying Act Of 2013.

[11] Department of Education (DepEd). (2017). DO 32, s. 2017 gender-responsive basic education policy | Department of Education. Retrieved from: https://bit.ly/3wmSMKm

[12] Fernandez, S. and H. Rainey (2006), "Managing successful organizational change in the public sector", Public Administration Review, Vol. 66/2, Pp. 168-176, Retrieved from: https://bit.ly/3poafzi

[13] Katz, Robert (1995) Harvard business review, titled "skills of an effective administrator" Retrieved from: https://bit.ly/3xu58R8

[14] Lactaotao, R. (2015). Implementation of child protection policy in tarlac east district schools: towards a plan of action. academia. Retrieved from: https://bit.ly/2rtpkow

[15] National Children's Alliance. 2019. National statistics on child abuse. Retrieved February 19, 2020 from: https://bit.ly/2snkt71

[16] Nattoo, Richard (2016). The complex world of school redesign: the building blocks and the builders by edsurge, Retrieved from https://bit.ly/3zneodf

[17] Naeem, M. (2014). Teachers understanding of child protection issues- pakistan. University of Oslo. Retrieved from: https://bit.ly/3gvyVC7

[18] Patzer, R. (2020, February). Sharing good practice: Strategies to Encourage Teacher Collaboration. Irisconnect.Com. Retrieved from: https://bit.ly/3cdk9bq

[19] Sheninger, E. (2016). A principal's reflection. reflections on teaching, learning, and leadership. Retrieved from https://bit.ly/3iElfHu

[20] United Nations Children's Fund (UNICEF). (2016a). Strengthening child protection systems in the philippines - child protection in emergencies. makati city: Unicef. Retrieved from https://bit.ly/3glNhWZ

[21] United Nations Children's Fund (UNICEF). (2016b). A Systematic Literature Review of The Drivers of Violence Affecting Children: The Philippines. Makati, Philippines: Author.

[22] United Nations Children's Fund (UNICEF). (2020). Impact of positive discipline. unicef myanmar. Retrieved from https://uni.cf/2SwLZ1Z

[23] United Nations Children's Fund (UNICEF). (2020). Unicef calls for protection of children under quarantine and children detained. unicef.org. Retrieved from https://uni.cf/3gsh3dv

[24] What is the Convention on the Rights of the Child? (2021). UNICEF. Retrieved from https://uni.cf/3pRzkTS

[25] World Health Organization (2016). Child mal- treatment fact sheet. Retrieved from https://bit.ly/3viQ7zZ 